\title{
PENGARUH MEWARNAI GAMBAR BINATANG UNTUK MENGURANGI PERILAKU HIPERAKTIF ANAK TUNARUNGU KELAS 1 DI SLB BC YPNI PAMEUNGPEUK KABUPATEN BANDUNG
}

\author{
An-Nisaa Pertiwi, Budi Susetyo "Penulis Penanggung Jawab", \\ Dudi Gunawan "Penulis Penanggung Jawab". \\ Departemen Pendidikan Khusus, Fakultas Ilmu Pendidikan, \\ Universitas Pendidikan Indonesia
}

\begin{abstract}
Abstrack
Hyperactive behavior shown by subjects such as legs and arms move when sitting (can not bi silent), disturbing others, did not follow instructions, leaving the seat, throw objects or stationery, excessive talking, spitting, and can not wait for their trun. Hyperactive behavior is very disturbing teaching and learning, others, and the subject itself. Therefore, needs tobe a form of diversion to reduce his hyperactive behavior. The study aims to determine the effect of coloring pictures of animals to reduce hyperactive behavior of children with hearing impairment. AG is one of the seven-years-old deaf child who is now sitting in class one in SLB BC YPNI Pameungpeuk Kab Bandung. For this study we used an experimental method with a single subject research, with A-B-A. The results of measurements using incident recording system, the baseline- 1 as much $91,50 \%$. Then the intervention condition (B) the frecuency of hyperactive behavior amounted to $70,75 \%$. Besides the frecuency of hyperactive behavior in baseline conditions- 2 to obtain the results as much as $61,75 \%$, which means there is good progress on the subjects hyperactive behavior decreases. Thus it can be concluded that the coloring pictures of animals have effect reduces hyperactive behavior AG.
\end{abstract}

Key word : Coloring, Picture of Animals, Hyperactive Behavior Deaf Children.

\begin{abstract}
Abstrak
Perilaku hiperaktif yang ditunjukan oleh subjek seperti kaki dan tangan bergerak saat duduk (tidak bisa diam), mengganggu orang lain, tidak mengikuti instruksi, meninggalkan tempat duduk, melempar benda atau alat tulis, berbicara berlebihan, meludah, dan tidak sabar menunggu giliran. Perilaku hiperaktif tersebut sangat mengganggu proses belajar mengajar, orang lain, dan diri subjek itu sendiri. Penelitian ini bertujuan untuk mengetahui pengaruh mewarnai gambar binatang untuk mengurangi perilaku hiperaktif anak tunarungu. AG adalah satu anak tunarungu yang berusia 7 tahun yang kini duduk di kelas satu di SLB BC YPNI Pameugpeuk. Untuk penelitian ini maka digunakan metode eksperimen dengan pendekatan SSR dan desain penelitian A-B-A. Hasil yang diperoleh dari pengamatan, frekuensi perilaku hiperaktif pada baseline-1 sebanyak 91.5\% Kondisi intervensi, frekuensi sebesar 70.75\%. Kemudian kondisi baseline-2 sebanyak $61,75 \%$ ini menunjukan bahwa perilaku hiperkatif mengalami penurunan atau positif. Dengan demikian dapat disimpulkan mewarnai gambar binatang memberikan pengaruh pada penurunan setiap aspek perilaku hiperaktif pada AG.
\end{abstract}

Kata Kunci : Mewarnai, Gambar binatang, Perilaku Hiperaktif Tunarungu.

\section{PENDAHULUAN}

Sekolah merupakan sebuah wadah untuk memberikan pengembangan pada anak, baik dalam bidang akademik maupun tingkah laku. Kemampuan akademik dan tingkahlaku sangat bergantung pada proses belajar yang didapatkan dalam kegiatan pembelajaran. Proses belajar mengajar yang di terapkan di sekolah-sekolah harus mengacu pada aspek pemahaman terhadap nilai dan sikap dalam pengembangan potensi dan kepribadian dirinya. Sekolah melayani anak sesuai dengan kebutuhannya termasuk sekolah umum maupun sekolah luar biasa, 
pelayanan pendidikan yang di berikan pada anak pun harus sesuai dengan kebutuhannya, tidak terkecuali pada anak tunarungu. Kesulitan mendengar pada anak tunarungu menyebabkan pemahaman bahasa menjadi terhambat dan menghasilkan penafsiran yang negatif. Menurut, Somantri (2007, hlm. 98) bahwa :

Kekurangan akan pemahaman bahasa lisan atau tulisan seringkali menyebabkan anak tunarungu menafsirkan sesuatu secara negatif dan ini sering menjadi tekanan bagi emosinya. Tekanan pada emosinya itu dapat menghambat perkembangan pribadinya dengan menampilkan sikap menutup diri, bertindak agresif, atau sebaliknya menampakkan kebimbangan dan keragu-raguan.

Kekurangan pemahaman bahasa ini sangat berdampak pada aspek sosial dan emosi/perilaku.

Emosi anak tunarungu selalu bergolak di satu pihak karena kemiskinan bahasanya dan di pihak lain yang karena pengaruh dari luar yang diterimanya. Permasalahan emosi dan sosial yang timbul akibat dari dampak ketunarunguan itu mengakibatkan anak tidak bisa berinteraksi dengan orang lain, hanya bergantung pada orang lain, perilaku anak tidak mau diam dalam waktu yang lama, memukul, menangis, mengganggu temannya. Perilaku itu cenderung mirip karateristik dari perilaku hiperaktif karena sulit untuk mengatur diri sendiri dalam suatu lingkungan yang semestinya. Menurut Barkley (1991, hlm. 62) menyatakan“... lemahnya kemampuan untuk mengatur perilaku untuk tujuan sekarang dan masa depan, serta sulit beradaptasi sosial dan perilaku dengan tuntutan lingkungan."

Pada kenyataanya dari hasil studi pendahuluan di SLB BC YPNI Pameungpeuk, terdapat salah satu anak tunarungu kelas D1 yang indikasi memiliki kecenderungan perilaku hiperaktif yang frekuensinya tidak seperti anak tunarungu di lingkungan sekitarnya. Perilaku yang ditunjukan seperti; kaki dan tangan bergerak saat duduk (tidak bisa diam), meninggalkan tempat duduk di kelas, seperti tidak menyimak dan mendengarkan saat diajak bicara langsung, suka mengganggu teman, mendorong, melempar alat-alat tulis, memukul teman, meludah, dan saat sedang berdo'a memulai pembelajaran, anak tersebut tidak mengikuti dengan baik tetapi menggganggu temannya dan meninggalkan tempat duduk, serta berlari-lari keluar kelas. Begitupun, pada saat pelaksanaan pembelajaran olahraga anak tersebut melakukan hal yang sama dan mengerjakan apa yang dia mau serta tidak mau menunggu giliran dan memberikan kesempatan bagi temannya terlihat pada saat bermain trampolin di luar kelas.

Hal ini tentunya akan sangat merugikan bagi anak itu sendiri, karena akibat dari perilakunya tersebut anak tidak akan mampu mengikuti proses pembelajaran sehingga kemampuan akademik anak tersebut tidak bisa berkembang serta akan dijauhi atau tidak disukai oleh temantemannya. Hal yang sudah dilakukan oleh guru hanya memarahi anak, namun kadangkadang hanya membiarkannya. Untuk itu peneliti menggunakan suatu pendekatan dengan memberikan suatu kegiatan yang menyenangkan dan nyaman. Kegiatan itu 
adalah mewarnai gambar. Mewarnai dipilih karena kegiatan ini sangat mudah dilakukan dan sangat di sukai oleh subjek. Selain itu, mewarnai adalah sarana yang baik untuk menyalurkan imajinasi ke dalam goresan garis warna pada bidang kosong.

Menurut Olivia, F. (2013, hlm. 21) bahwa "mewarnai merupakan suatu bentuk kegiatan kreativitas dimana anak diajak memberikan satu atau beberapa goresan warna pada suatu bidang atau pola gambar, sehingga terciptalah suatu kreasi seni." Terutama, anakanak pada dasarnya selalu memiliki sifat ingin tahu pada kreativitasnya. Selain itu melalui kegiatan mewarnai gambar, anak-anak dapat mengekspresikan dirinya dengan baik.

Banyak sekali pola gambar yang bisa diwarnai seperti mewarnai pola binatang yang sederhana sampai rumit. Pola gambar yang dimaksud dalam penelitan ini yaitu mewarnai pola-pola gambar binatang berupa ayam, kucing, anjing, ikan, sapi, kelinci, dan kuda. Pola gambar tersebut di pilih karena sangat disukai oleh anak dan mudah ditemukan di lingkungan rumah dan sekitarnya. Tujuan dari mewarnai gambar binatang ini yaitu untuk melatih kemampuan konsentrasi dan koordinasi organ visual serta motorik halus pada anak. Selain itu dapat menyalurkan emosi anak ke hal yang lebih positif dan dapat mengenalkan macam-macam binatang pada anak. Kemudian dengan mewarnai pola gambar binatang itu diharapkan dapat mengurangi perilaku hiperaktif pada anak.

Berdasarkan hal diatas, peneliti merasa perlu menganggkat permasalahan tersebut, pemberian intervensi yang bertujuan agar anak tunarungu dapat mengurangi perilaku hiperaktif dapat berkurang atau menurun, sehingga anak dapat diterima dengan baik di lingkungan ia berada.

\section{METODE PENELITIAN}

Variabel dalam penelitian single subject variabel bebas atau variabel independen disebut variabel stimulus, prediktor, antecendent. Sedangkan variabel terikat atau disebut variabel dependen sebagai variabel output, kriteria, dan konsekuen atau disebut juga target behavior.

Variabel bebas dalam penelitian ini adalah mewarnai gambar binatang sebagai perlakuan untuk mengurangi perilaku hiperaktif. Mewarnai adalah suatu aktivitas yang menyenangkan dan bisa dilakukan oleh anak termasuk anak tunarungu yang memiliki gejala perilaku hiperaktif. Anak hiperaktif harus di paparkan pada warna supaya anak lebih tenang dan nyaman. Menurut Zavierra (2009, hlm. 34) "Sekedar sebagai pendamping, terapi ini menyarankan agar anak hiperaktif dipaparkan pada warnawarna". Karena warna dapat menstimulasi otak anak agar bisa memusatkan perhatian pada suatu pekerjaan atau tugas. Objek yang diwarnai di dalam penelitian ini yaitu mewarnai gambar binatang dikarenakan gambar binatang lebih menarik. Bilamana anak tertarik mewarnai gambar binatang secara terus menerus hal ini akan berdampak pada perilaku yang positif sehingga hal ini dapat mengurangi perilaku pada anak. Selain itu, tulisan atau gambar anak bisa mengungkapan emosinya secara bebas seperti yang dinyatakan oleh Zaviera (2009, hlm 29) "biasakan anak mengekspresikan emosinya dalam bentuk tulisan dan gambar". 
Variabel terikat dalam penelitian ini adalah "Mengurangi Perilaku Hiperaktif Anak Tunarungu". Perilaku hiperaktif merupakan suatu pola tingkah laku yang tidak dikehendaki oleh individu yang mengalaminya maupun orang lain yang merasa terganggu dengan gejala tersebut. Menurut Zaviera (2009, hlm. 45) dikatakan bahwa "Ciri-ciri dari hiperaktivitas adalah terus-menerus bergerak, memainkan jari atau kaki saat duduk, sulit duduk diam dalam waktu yang lama, berlarian atau memanjat secara berlebihan yang tidak sesuai dengan situasi, atau berbicara berlebihan." Selain itu gejalagejala impulisvitas dan perilaku hiperaktif menurut MIF. Baihaqi dan M. Sugiarmin (2008, hlm. 3) meliputi : Emosi gelisah, mengalami kesulitan bermain dengan tenang, mengganggu anak lain dan selalu bergerak. Dengan demikian dapat disimpulkan perilaku hiperaktif itu pola perilaku negatif seperti; tidak mau duduk diam, menggeliatkan badan, menangis dengan keras, memotong pembicaraan/menyela, berbicara berlebihan/ ecolalia, mengganggu teman, melempar benda semaunya, tidak mengikuti instruksi, memanjat, naik meja, meludah, dan tidak sabar menunggu giliran. hal-hal tersebut sangat merugikan diri individu sendiri maupun orang lain. Untuk menanganinya perlu modifikasi perilaku untuk mengubah perilaku yang tidak dikehendaki menjadi perilaku yang terarah. Perilaku hiperaktif yang terdapat pada subjek yang bernama AG seorang anak yang memiliki hambatan dalam pendengaran (tunarungu). Gejala yang timbul pada AG yaitu dikarenakan oleh faktor di dalam dirinya dan faktor eksternal yaitu kondisi subjek dilingkungan ia berada. ketidaktahuan subjek bergaul di dalam lingkungannnya menyebabkan timbulnya perilaku hiperaktif selain itu, faktor keluarga yang sering meninggalkan subjek, kurangnya perhatian karena ditinggalkan oleh orang tua yang pekerja. hal-hal ini berdampak pada emosi dan perilaku subjek sekarang. Target behavior yang akan di ubah pada AG yaitu kaki dan tangan bergerak saat duduk (tidak bisa diam), meninggalkan tempat duduk di kelas, seperti tidak menyimak dan mendengarkan saat diajak bicara langsung, suka mengganggu teman, mendorong, melempar alat-alat tulis, memukul teman, meludah, meninggalkan tempat duduk, serta berlari-lari keluar kelas.

\section{DESAIN PENELITIAN}

Metode yang digunakan dalam penelitian ini adalah metode eksperimen dengan subyek penelitian tunggal (Single Subject Reserch). Metode ini digunakan karena ingin meneliti suatu peristiwa perubahan yang muncul secermat mungkin, sehingga dapat diketahui hubungan sebab akibat munculnya gejala tersebut.

Seperti halnya yang dikemukakan oleh Arikunto (2010, hlm. 36 ) bahwa :

Eksperimen adalah suatu cara untuk mencari hubungan sebab akibat (hubungan kausal) antar dua faktor yang sengaja ditimbulkan oleh peneliti dengan mengeliminasi atau mengurangu atau menyisihkan faktor-faktor lain yang bisa mengganggu. Eksperimen selalu dilakukan dengan melihat akibat dari suatu perlakuan.

Metode eksperimen menurut Sunanto (1995, hlm. 115) adalah : "penelitian 
memanipulasi variabel independent (suatu stimulasi, treatment, atau kondisi ekperimental) kemudian mengobservasi pengaruh dari perubahan yang diakibatkan oleh manipulasi yang dilakukan”. Mengacu pada eksperimen dengan subyek tunggal, penelitian ini menggunakan disain A-B-A.

Penggunaan disain A-B-A ini untuk melihat adanya hubungan sebab-akibat antara variabel terikat dan variabel bebas lebih kuat dibandingkan dengan disain A-B. Disain A-B-A memilik tiga fase yaitu A-1 (baseline 1) $B$ (intervensi) dan A-2 ( baseline). Disain A-B-A bertujuan untuk mengetahui pengaruh dari perlakuan yang diberikan terhadap variabel yang diberikan kepada individu. Selain itu di dalam penelitan SSR dengan disain A-B-A bertujuan untuk memperoleh data sebelum subyek mendapatkan perlakuan atau intervensi, saat mendapatkan intevensi, dan sesudah mendapatkan perlakuan lalu, dilihat adakah perubahan setelah adanya pengaruh yang diberikan kepada subjek.

\section{SUBYEK PENELITIAN}

Penelitian ini menggunakan satu subyek yaitu, siswa kelas D1 di SLB BC YPNI Pameungpeuk. Adapun pertimbangan memilih subyek tersebut karena kemampuan untuk mengikuti pembelajaran di kelas belum begitu baik selain itu, yang paling menarik perhatian peneliti yaitu perilaku anak yang berbeda dari anak tunarungu lainnya.

\section{TEKNIK PENGUMPULAN DATA}

Teknik pengumpulan data dalam penelitian ini adalah observasi secara langsung. Menurut Sunanto, J. dkk (2006, hlm. 19), "prosedur pencatatan ini merupakan kegiatan observasi secara langsung yang dilakukan untuk mencatat data variabel terikat atau perilaku sasaran pada saat perilaku sedang terjadi". Pencatatan semacam ini merupakan dasar utama pengukuran dalam penelitian dengan kasus tunggal di bidang modifikasi perilaku.

Modifikasi perilaku berkaitan dengan perilaku yang akan di ubah, di kurangi dan diminimalisir. Jenis ukuran yang digunakan untuk mngukur target behavior adalah frekuensi. Menurut Sunanto, J dkk. (2005, hlm. 15) "frekuensi menunjukan berapa kali suatu peristiwa terjadi pada suatu periode waktu tertentu." Dalam pencatatan kejadian atau frekuensi menggunakan cara memberikan tanda (dengan memberi tally) pada kertas yang telah disediakan setiap kejadian atau perilaku terjadi sampai periode waktu observasi yang telah ditentukan. Target behavior perilaku hiperaktif siswa seperti tidak mau diam, suka mengganggu temannya, dan suka berlari-larian keluar kelas, melorotkan badan ke bawah meja dan menggoyang-goyangkan kepala.

Teknik observasi yang akan di lakukan meliputi :

1) Cara mendapatkan data yang menjadi baseline-1, peneliti sebelumnya melalukan pengamatan secara langsung pada situasi yang natural dengan kondisi subyek mengikuti pembelajaran di dalam kelas dengan melihat anak dalam hal menulis permulaan yaitu menebalkan garis dan angka.

2) Setelah memperoleh data baseline-1 yang dilaksakan selama 5 sesi dan diteruskan pada fase intervensi-1, yang dilaksanakan selama 8 sesi langkah selanjutnya adalah 
melakukan baseline-2 selama 5 sesi yaitu sebaga evaluasi dan intervensi-1. Waktu yang diperlukan untuk memperoleh data per-sesi selama 3 x 30 menit atau selama pembelajaran di mulai dari jam 8.00 sampai 9.30 WIB.

\section{INSTRUMEN PENELITIAN}

Penyusunaninstrumenharus berpedoman pada pendekatan yang digunakan agar data yang dikumpulkan dapat dijadikan dasar untuk menguji hipotesis.

Menurut Arikunto (2010, hlm. 203) mengatakan bahwa:
Instrumen penelitian adalah alat atau fasilitas yang digunakan oleh peneliti dalam mengumpulkan data agar pekerjaannya lebih mudah dan hasilnya lebih baik, dalam arti lebih cermat, lengkap, dan sistematis sehingga lebih mudah diolah.

Sebelum membuat instrumen dibutuhkan adanya 'kisi-kisi'. Menurut Arikunto (2010, hlm. 205) bahwa, "kisi-kisi adalah sebuah tabel yang menunjukan hubungan antara halhal yang disebutkan dalam baris dengan halhal yang disebutkan dalam kolom”. Adapun kisi-kisi instrumen yang digunakan dalam penelitian ini sebagai berikut :

Tabel 3.1

Kisi-Kisi Instrumen Perilaku Hiperaktif

\begin{tabular}{|c|c|c|c|c|}
\hline Variabel & Pola Perilaku & Aspek Yang Diamati & Durasi & Evaluasi \\
\hline \multirow[t]{15}{*}{$\begin{array}{l}\text { Perilaku } \\
\text { Hiperaktif }\end{array}$} & \multirow[t]{7}{*}{ Hiperaktivitas } & $\begin{array}{l}\text { Kaki dan tangan bergerak saat } \\
\text { duduk (tidak bisa diam) }\end{array}$ & \multirow[t]{15}{*}{30 menit } & \multirow{15}{*}{$\begin{array}{c}\text { Lembar } \\
\text { pengamatan } \\
\text { perilaku } \\
\text { hiperaktif }\end{array}$} \\
\hline & & Meninggalkan tempat duduk & & \\
\hline & & $\begin{array}{l}\text { Seperti Tidak mendengarkan bila } \\
\text { diajak bicara langsung }\end{array}$ & & \\
\hline & & Menyela pembicaraan & & \\
\hline & & Berbicara sendiri/berlebihan & & \\
\hline & & Mengganggu teman & & \\
\hline & & Berlarian kesana-kemari & & \\
\hline & \multirow[t]{8}{*}{ Impulsifitas } & Memukul teman & & \\
\hline & & Naik meja & & \\
\hline & & Memanjat & & \\
\hline & & Melempar benda atau alat tulis & & \\
\hline & & Menendang teman & & \\
\hline & & Tidak mengikuti instruksi & & \\
\hline & & Meludah & & \\
\hline & & Tidak menunggu giliran & & \\
\hline
\end{tabular}

Setelah membuat kisi-kisi instrumen beserta penialiannya kemudian membuat alat atau instrumen. Instrumen yang digunakan oleh peneliti dalam peneitian ini adalah alat berupa pedoman observasi yang dirancang dari target behavior (terlampir) yang isinya merupakan butir-butir perilaku hiperaktif yang dijadikan indikator dalam penelitian. Instrumen penelitian dapat digunakan apabila instrumen itu dinyatakan valid. Menurut Arikunto (2010, hlm. 211) "validitas adalah suatu ukuran yang menunjukan tingkattingkat kevalidan atau keshahihan suatu instumen". Suatu instrumen yang baik 
dapat mengukur variabel yang akan diteliti secara tepat. Maka dari itu instrumen yang valid akan ditentukan oleh hasil pendapat dari para ahli (expert judgement). "para ahli diminta pendapatnya tentang instrumen yang telah disusun itu, mungkin para ahli akan memberikan keputusan: instrumen dapat digunakan tanpa perbaikan, ada perbaikan dan mungkin dirombak total" (Sugiyono, 2014, hlm 177). Berikut adalah penilaian ahli yang menilai kelayakan instrumen yang dibuat oleh peneliti :

Tabel 3.2

Data Tim Expert Judgment

\begin{tabular}{|c|c|c|}
\hline No. & Nama & Jabatan \\
\hline 1. & E.R & Dosen Pendidikan Khusus UPI \\
\hline 2. & N.W & Dosen Pendidikan Khusus UPI \\
\hline 3. & S.M & Dosen Pendidikan Khsus UPI \\
\hline 4. & K.K & $\begin{array}{l}\text { Kepala Sekolah SLB BC YPNI } \\
\text { Pameungpeuk }\end{array}$ \\
\hline 5. & N.S & $\begin{array}{lrll}\text { Guru } & \text { SLB } & \text { BC } & \text { YPNI } \\
\text { Pameungpeuk } & & \end{array}$ \\
\hline
\end{tabular}

Perhitungan kecocokan terhadap validitas isi dengan menggunakan rumus (Susetyo, 2011, hlm. 92) :

$$
\text { Persentase }=\frac{f}{\Sigma f} \times 100 \%
$$

dimana;

$\mathrm{f}=$ frekuensi cocok menurut penilai

$\Sigma \mathrm{f}=$ jumlah peniilai

Setelah melakukan validitas dengan menggunakan penilaian ahli dan keseluruhan butir instrumen dinyatakan valid, selanjutnya melakukan uji coba instrumen. Uji coba instrumen dilakukan oleh dua orang pengamat dengan melihat format perilaku sasaran yaitu perilaku hiperaktif pada lembar pengamatan selama 30 menit.
Karena penelitian ini merupakan penelitian modifikasi perilaku sering melakukan pengukuran dan pencatatatn kejadian. Maka untuk mengetahui pencatatan data tersebut reliabel atau belum perlu menghitung persentase kesepakatan. Menurut Sunanto, dkk. (2006, hlm. 24) bahwa

"Pengukuran data yang reliabel merupakan salah satu syarat mutlak yang harus dipenuhi dalam penelitian. Realibilitas data penelitian sangat menentukan kualitas penelitian. Agar hasil penelitian dapat dipercaya salahsatunya data harus reliabel. Realibilitas menunjukan sejauh mana pengukuran data dapat diukur secara ajeg."

Sama halnya pengertian reliabel menurut Darmadi (2013, hlm. 109) bahwa “... instrumen yang reliabel ialah instrumen yang apabila digunakan terhadap subjek yang sama, akan menunjukan hasil yang sama, walaupun dilaksakan dalam kondisi dan wkatu yang berbeda". Selain itu, suatu perangkat ukur yang dapat dipercaya adalah alat ukur yang hasilnya tidak berubah atau hasilnya relatif sama jika dilakukan pengetesan secara berulang-ulang dan alat ukur yang demikian dinamakan dengan reliabel (Susetyo, 2011, hlm. 105). Adapun beberapa cara dalam melakukan penilaian realibilitas perangkat ukur salah satunya dengan kecocokan penilai dan pengamat. Teknik kecocokan semacam ini merupakan realibilitas yang sejenis dengan realibilitas ekuivalen dan lebih tepat digunakan responden yang tidak terlalu banyak. Hasil penilaian pada aspek perilaku hiperaktif dengan subjek tunarungu di sajikan dalam tabel sebagai berikut; 
Tabel 3.4

Sekor Hasil Pengamatan pada Perilaku Hiperaktif Subjek

\begin{tabular}{|c|c|c|}
\hline $\begin{array}{c}\text { Aspek yang } \\
\text { diamati }\end{array}$ & $\begin{array}{c}\text { Penilai } \\
\mathbf{X}\end{array}$ & Penilai Y \\
\hline 1 & 4 & 4 \\
\hline 2 & 3 & 3 \\
\hline 3 & 1 & 1 \\
\hline 4 & 2 & 2 \\
\hline 5 & 3 & 3 \\
\hline 6 & 4 & 3 \\
\hline 7 & 4 & 3 \\
\hline 8 & 2 & 2 \\
\hline 9 & 1 & 1 \\
\hline 10 & 1 & 1 \\
\hline 11 & 4 & 4 \\
\hline 12 & 1 & 1 \\
\hline 13 & 4 & 4 \\
\hline 14 & 3 & 2 \\
\hline 15 & 4 & 3 \\
\hline
\end{tabular}

Dari hasil peniali kedua pengamat diolah dengan menggunakan korelasi product moment dengan rumus (Susetyo, 2011. hlm 135) :

$\rho \mathrm{x}_{\mathrm{y}}=\frac{N \Sigma X Y-(\Sigma X)(\Sigma Y)}{\sqrt{\left[\left(N \Sigma X^{2}-(\Sigma X)^{2}\right]\left[N \Sigma Y^{2}-(\Sigma Y)^{2}\right]\right.}}=0,935$

Hasil Koefisien korelasi yang diperoleh adalah 0,935 tergolong sangat tinggi, oleh karena itu disimpulkan terdapat kecocokan penilaiaan diantara dua pengamat berarti perangkat ukur yang dibuat reliabel.

\section{HASIL DAN PEMBAHASAN}

Hasil penelitian menunjukan adanya pengaruh dari hasil intervensi atau perlakuan yang berupa mewarnai gambar binatang untuk mengurangi perilaku hiperaktif pada subjek. Hasil tersebut bisa digambarkan pada grafik di bawah ini :

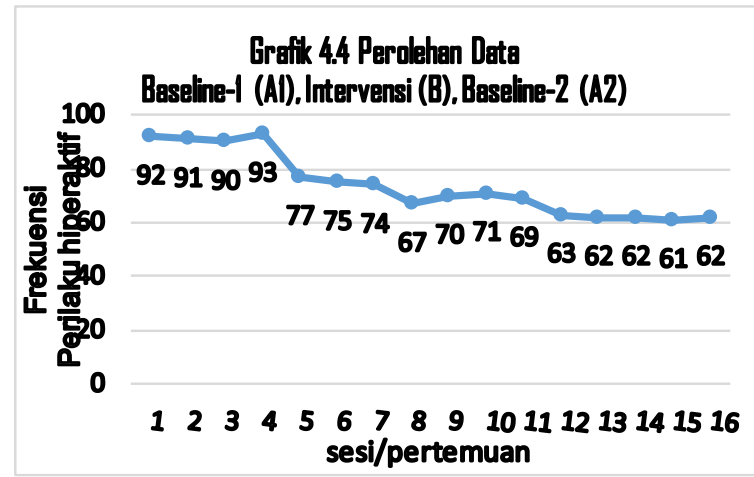

Pada Grafik 4.4 Menjelaskan frekuensi perilaku hiperaktif pada setiap sesinya. Terlihat pada fase baseline-1 (A1) frekuensi perilaku hiperaktif sangat tinggi dan menurun pada saat fase intervensi (B) diikuti penurunan frekuensi pada kondisi fase baseline-2 (A2). Secara jelas penurunan frekuensi perilaku hiperaktif dapat terlihat pada grafik 4.4.

Pembahasan lebih lanjut yaitu subyek dalam penelitian ini adalah peserta didik tunarungu kelas 1 yang memiliki karakteritik perilaku hiperaktif. Menurut Azmira, V (2015) "Anak hiperaktif adalah anak yang mengalami gangguan saraf tertentu sehingga sulit memusatkan konsentrasi dan cenderung hiperkinetik (terlalu banyak bergerak)". Menurut hasil wawancara pada guru dan orang tua secara tidak terstruktur, melihat kondisi subyek di sekolah maupun dirumah perilaku subyek sangat berlebihan seolaholah motoriknya tidak mau berhenti dan mengontrol perilakunya tersebut. Penyebab hiperaktif pada subyek adalah riwayat saat kehamilan, ibu mengalami sakit dan mengkonsumsi obat-obat tanpa konsultasi ke dokter. Selain itu faktor lingkungan pada anak di lingkungan ia tinggal serta faktor emasional pada subyek yang tidak stabil menyebabkan perilaku hiperaktif. 
Pada penelitian ini yang menjadi fokus penelitian adalah karekteristik-karakteristik perilaku hiperaktif yang menjadi target behavior diamati selama 30 menit dalam setting kegiatan belajar mengajar dikelas. Frekuensi perilaku hiperaktif subyek pada baseline-1 (A-1) yaitu sesi ke-1 sebesar 92, sesi ke-2 sebesar 91, sesi ke-3 sebesar 90, dan sesi ke-4 sebesar 93, perubahannya meningkat dan hal ini menunjukan kecenderungan arah yang artinya memburuk. Kemudian proses intervensi dilakukan dengan mewarnai gambar binatang, karena subyek sangat menyukai binatang-binatang terutama binatang yang sering ia jumpai di lingkungan rumahnya seperti ayam, ikan, kuda, kucing, sapi, dan anjing. Hasil intervensi mendapatkan frekuensi subyek menurun dengan jumlah sesi ke-5 sebesar 77, sesi ke-6 sebesar 75, sesi ke-7 sebsesar 74, sesi ke- 8 sebesar 67 sesi ke-9 sebesar 70 , sesi ke-10 sebesar 71, sesi ke-11 sebesar 69, dan sesi ke-12 sebesar 63. Kemudian hasil baseline-2 (A-2) frekuensinya menurun yaitu sesi ke-13 sebesar 62, sesi-ke 14 sebesar 62 , sesi ke-15 sebesar 61, sesi ke-18 sebesar 62 .

Melihat perbandingan frekuensi subjek dari baseline-1 (A-1), Intervensi (B), dan baseline-2 mengalami penurunan. Hal ini dipengaruhi oleh bentuk intervensi yang diberikan yaitu berupa mewarnai gambar binatang. Menurut Menurut Olivia (2013, hlm. 23) mengatakan bahwa "Mewarnai adalah suatu bentuk kegiatan kreativitas, dimana anak diajak untuk memberikan satu atau beberapa goresan warna pada suatu bentuk atau pola gambar, sehingga terciptalah sebuah kreasi seni." Selain itu Eli Wibawati (2013, hlm. 14) mengatakan bahwa "Mewarnai adalah kegiatan yang menyenangkan dan mudah untuk di lakukan."

Selama intrevensi berlangsung subyek mendapatkan perlakuan yang mengalihkan perilaku hiperaktif nya. Hal ini menunjukan adanya penurunan frekuensi perilaku hiperaktif pada baseline-2 (A-2) menurun. Namun masih terdapat kekurangan pada saat intervensi yang dilakukan secara terus menerus membuat subyek menjadi bosan, membuat perhatiannya terkadang teralihkan, menolak, dan menggeserkan lembar mewarnainya. Mengatasi hal tersebut peneliti harus mengkondisikan subyek terlebih dahulu. Pengkondisian subyek dilakukan dengan cara memberi hadiah berupa kue, permen, dan mainan. Selain itu kondisi lingkungan yang banyak terdapat bendabenda sehingga subyek lebih tertarik dan akhirnya meninggalkan tempat duduk untuk mengambil benda-benda tersebut. Selain itu menganggu teman, melemparkan barang serta tidak mau mendengarkan instruksi peneliti.

Maka dari itu kegiatan mewarnai gambar binatang ini bukan menghilangkan perilaku hiperaktif secara mutlak tetapi dapat mengurangi sebagian karakteristik perilaku hiperaktif yang menjadi target behavior. Selain itu perlu ada variasi kegiatan aktivitas tangan maupun kegiatan motorik lain dalam memberikan intervensi. Pengkondisian waktu serta penempatan subyek dalam ruang kelas harus diperhatikan agar tujuan dari intervensi dapat memberikan hasil yang signifikan.

\section{KESIMPULAN}

Berdasarkan seluruh hasil analisis data yang diperoleh dilapangan, baik data pada 
kondisi baseline-1 (A1), intervensi (B), maupun setelah intervensi yaitu baseline-2, mengenai pengaruh mewarnai gambar binatang untuk mengurangi perilaku hiperaktif anak tunarungu kelas I di SLB BC YPNI Pameungpeuk Kab Bandung, maka dapat ditarik kesimpulan sebagai berikut:

Kegiatan mewarnai gambar binatang yaitu pola gambar ayam, anjing, sapi, ikan, kuda, dan kucing memberikan pengaruh positif terhadap penurunan frekuensi perilaku hiperaktif pada subjek yang diteliti. Bentuk perilakunya yaitu kaki dan tangan tidak mau diam saat duduk, mengganggu teman, melempar alat tulis, tidak mengikuti instruksi, meludah, dan tidak sabar menunggu giliran dilihat pada data baseline-1. Perilaku hiperaktif pada subjek menunjukan kondisi baseline-1 (A1) persentase sebesar 91.5\%, yang artinya frekuensi perilaku hiperaktif subjek memburuk atau negatif, dan kondisi intervensi (B) sebesar 70,75\% pada kondisi ini mengakami penurunan yang artinya membaiik atau positif, dan kondisi baseline-2 (A2) sebesar $61,75 \%$ artinya, penurunan perilaku hiperaktifnya semakin baik mengalami penurunan. Dengan demikian, mewarnai gambar binatang memberikan pengaruh untuk mengurangi perilaku hiperaktif pada subjek yang di teliti yaitu AG. Selain perilaku hiperaktif yang ditunjukan oleh subjek mengalami kemajuan dengan berubahnya perilaku subjek serta perkembangan dalam aspek menulisnya pun berkembang. Walaupun penurunan perilaku hiperaktif seperti kaki dan tangan bergerak saat duduk, meninggalkan tempat duduk, melempar alat tulis, memukul, tidak sabar menunggu giliran, meludah, dan tidak mengikuti instruksi yang ditunjukan oleh subjek masih belum mengalami penurunan frekuensi secara signifikan. Dikarenakan masih dalam keterbatasan baik dari segi waktu maupun dari subjek itu sendiri. Sehingga perlu adanya perbaikan pada setiap kondisi intervensi yang akan diberikan pada penelitian berikutnya apabila ada yang berkenan melanjutkan.

\section{Saran}

Bagi Guru kelas selain bisa memberikan kegiatan yang menyenangkan seperti halnya dilakukan peneliti yaitu mewarnai gambar binatang untuk mengurangi perilaku hiperaktif.Adapunhal lainyang bisa dilakukan agar pemberian pembelajaran tidak monoton, yaitu mengajak subjek untuk melakukan aktivitas motorik kasar seperti melompat, berjalan memutari lapangan sekolah, berlari dan lain-lain. Dengan mengkombinasikan pembelajaran yang melakukan kegiatan fisik terutama pada anak yang memiliki perilaku hiperaktif hal ini bisa meminimalisir perilaku yang tidak semestinya dilakukan oleh subjek. Sehingga pembelajaran yang akan dilakukan oleh subjek akan bervariasi dan bermakna. 